\title{
Cyclooxygenase-2 Inhibition Enhances Proliferation of NKT Cells Derived from Patients with Laryngeal Cancer
}

\author{
JANUSZ KLATKA ${ }^{1}$, EWELINA GRYWALSKA ${ }^{2}$, ANNA HYMOS ${ }^{1}$, MAŁGORZATA GUZ ${ }^{3}$, \\ KRZYSZTOF POLBERG ${ }^{4}$, JACEK ROLIŃSKI ${ }^{2}$ and ANDRZEJ STEPULAK ${ }^{3}$ \\ ${ }^{1}$ Department of Otolaryngology and Laryngeal Oncology, Medical University of Lublin, Lublin, Poland; \\ ${ }^{2}$ Department of Clinical Immunology and Immunotherapy, Medical University of Lublin, Lublin, Poland; \\ ${ }^{3}$ Department of Biochemistry and Molecular Biology, Medical University of Lublin, Lublin, Poland; \\ ${ }^{4}$ Department of Otolaryngology, MSW Hospital, Lublin, Poland
}

\begin{abstract}
Background/Aim: The aim of this study was to analyze whether inhibition of cyclooxygenase-2 by celecoxib and the subsequent enhancement in the proliferation of natural killer $T$ (NKT) cells could play a role in dendritic cell (DC)-based laryngeal cancer $(L C)$ immunotherapy. Patients and Methods: Peripheral blood mononuclear cells were obtained from 48 male patients diagnosed with $L C$ and 30 control patients without cancer disease. Neoplastic cell lysate preparations were made from cancer tissues obtained after surgery and used for in vitro DCs generation. NKT cells proliferation assay was performed based on ${ }^{3} H$-thymidine incorporation assay. Results: An increased proliferation of NKT cells was obtained from control patients compared to NKT cells obtained from LC patients regardless of the type of stimulation or treatment. In the patient group diagnosed with LC, COX-2 inhibition resulted in a significantly enhanced proliferation of NKT cells when stimulated with autologous DCs than NKT cells stimulated with DCs without COX-2 inhibition. These correlations were not present in the control group. Higher proliferation rate of NKT cells was also observed in non-metastatic and highly differentiated LC, which was independent of the type of stimulation or treatment. Conclusion: COX-2 inhibition could be regarded as immunotherapy-enhancing tool in patients with $L C$.
\end{abstract}

Increasing morbidity and unsatisfactory treatment efficacy of laryngeal carcinoma (LC)-bearing patients require the development of new more effective therapy schemes, including immunotherapy with the use of dendritic cells $(\mathrm{DCs})(1,2)$.

Correspondence to: Andrzej Stepulak, Department of Biochemistry and Molecular Biology, Medical University of Lublin, Chodźki 1 Street, 20-093 Lublin, Poland. Tel/Fax: +48 814486350, e-mail: andrzej.stepulak@umlub.pl

Key Words: NKT cells, cyclooxygenase-2 inhibitor, dendritic cells, proliferation.
Unfortunately, due to the complexity of DCs biology, and the fact that influence of cancer antigens on DCs functions is not fully established as well as interactions between various types of immune cells, an optimal method of treatment with DCs in LC patients has not been yet developed $(3,4)$.

Up-regulation of tumor cyclooxygenase 2 (COX-2) has been described in several malignancies including squamous cell carcinoma of the head and neck (HNSCC) $(5,6)$. COX2 plays an important role in cancer progression by increasing cancer cells proliferation, reducing apoptosis, promoting local tumor invasiveness and angiogenesis (7). Recent studies have emphasized the influence of tumor-derived COX-2 on induction and accumulation of different types of immune suppressor cells including T regulatory cells (Treg) (8).

Natural killer T (NKT) cells are a subpopulation of immunoregulatory $\mathrm{T}$ cells that bridge innate and adaptive immune responses (9). NKT cells respond to stimulation and acquire cytotoxic properties under the influence of cytokines including IL-12 (10), released by DCs and macrophages in the presence of CD1d complex (11). Recent findings indicated that DCs are particularly potent in activating NKT cells and to trigger NKT cell-based innate anticancer immune responses $(12,13)$.

The aim of this study was to evaluate the effect of COX2 inhibition on the proliferation of DCs-stimulated NKT cells, derived from LC patients and patients from the control group in order to address the rationale of using these cells in immunotherapy of LC-bearing patients. Additionally, intensity of NKT cell proliferation has also been correlated with clinical and histological features, including TNM classification and histological grade of laryngeal tumors.

\section{Patients and Methods}

Patients. A total of 48 male patients diagnosed with squamous cell carcinoma of the larynx and thirty male patients without cancer disease (control group, CG) were selected and included in the study. The diagnosis of cancer was established after histopathological 
A

NKT cells

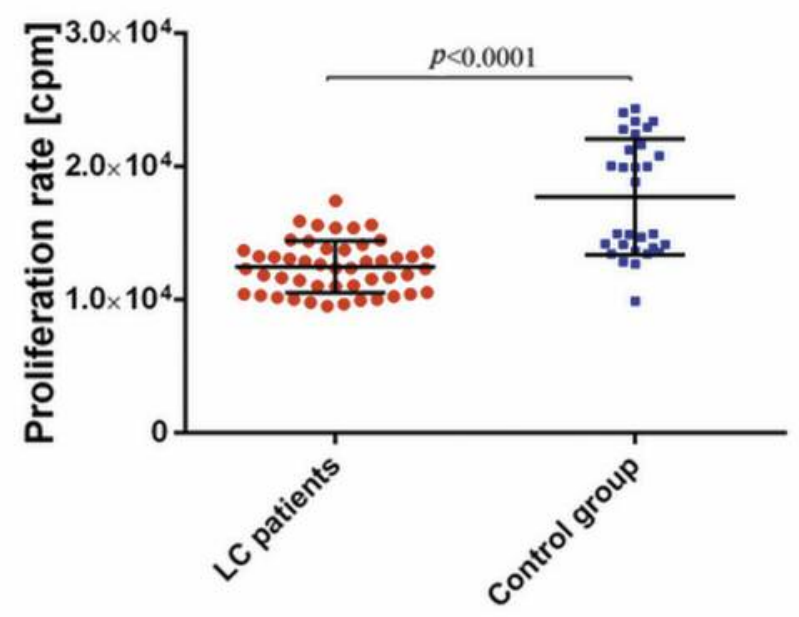

C

NKT cells and DC

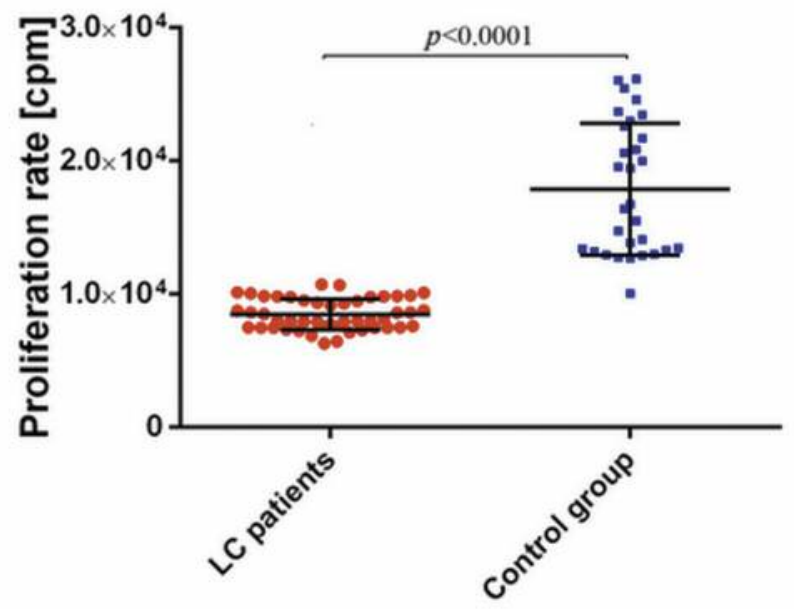

B

\section{NKT cells and COX-2 inhibitor}

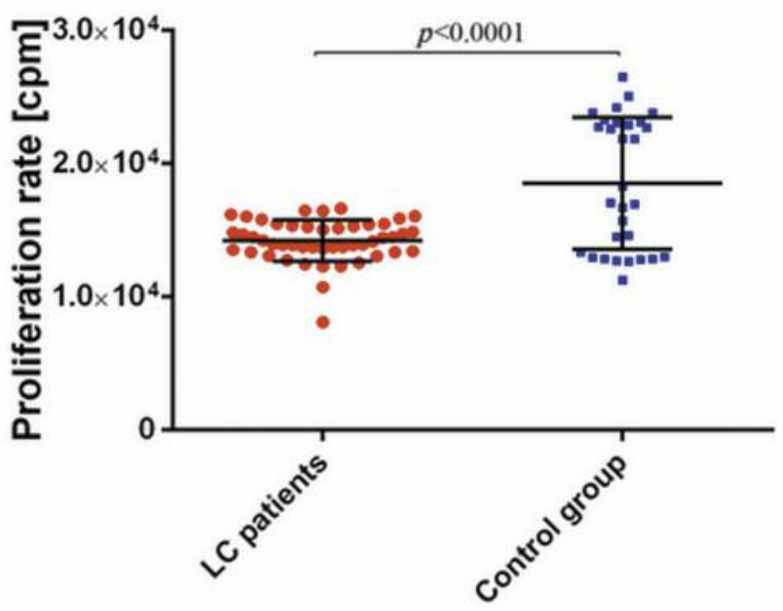

D

\section{NKT cells with DC and COX-2 inhibitor}

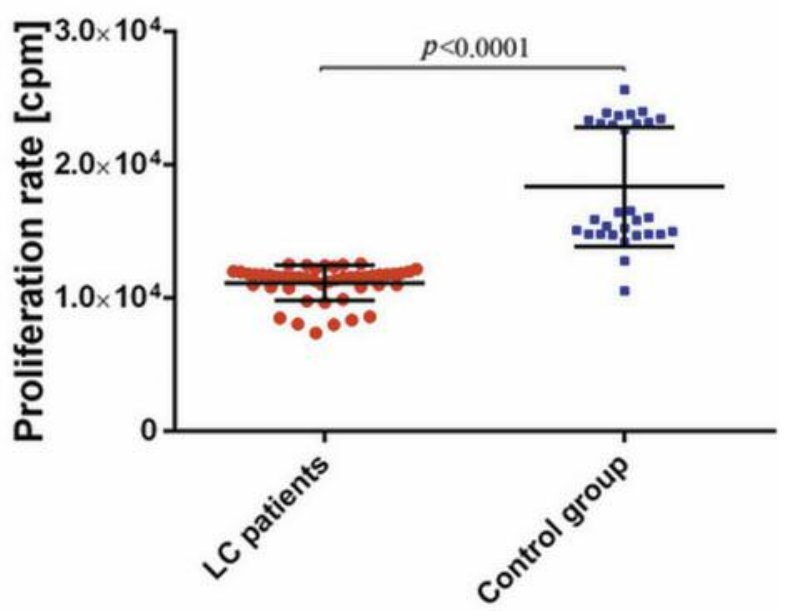

Figure 1. Comparison of proliferation rate of NKT cells in larynx cancer (LC) patients and control group (healthy individuals).

examinations of tumor samples. All LC-bearing patients underwent surgery - total or partial laryngectomy, followed by additional necessary treatment (radiotherapy, chemotherapy). Patients enrolled into the study did not receive any preoperative treatment. None of the LC patients and patients from CG had signs of infection at the time of investigation and for a month before surgery. None of the patients had been taking drugs of known influence on the immune system. None of the LC or CG patients had undergone blood transfusion. Peripheral blood WBC was within the normal range between 4 and $10 \mathrm{G} / \mathrm{L}$. Persons with allergic diseases in anamnesis were excluded from the study. The mean age of LC and CG patients was similar, 62.21 \pm 11.98 years (ranging from 44 to 76 years; median 63.5), and $61.14 \pm 12.47$ (ranging from 43 to 75 years; median 60.25), respectively. A summary of patients' characteristics is presented in Table I. The research protocol was approved by the local Ethical Committee (No KE-0254/226/2010) and all patients gave written informed consent.

Cell isolation and cell cultures. Isolation of the peripheral blood mononuclear cells, preparation of the neoplastic cell lysates and dendritic cells generation were performed as described in our previous work (1).

NKT cells were isolated from the peripheral blood mononuclear cells from LC and GC patients, using anti-iNKT antibodies coating MicroBeads (Miltenyi Biotec, USA), which enable a positive selection of NKT cells expressing TCR V $\alpha 24-J \alpha 18$ and V $\beta 11$. The separation conditions were analogous to those described previously (1). NKT cells were cultured under standard conditions $\left(37^{\circ} \mathrm{C}, 5 \%\right.$ CO2) in RPMI 1640 medium (PAA Laboratories, Austria), enriched with $2 \%$ human albumin (Baxter, USA) and supplemented with 
Table I. LC patients' characteristics.

\begin{tabular}{|c|c|c|c|c|c|c|c|c|c|c|c|c|}
\hline \multirow[t]{3}{*}{ Clinical feature } & \multicolumn{3}{|c|}{$\begin{array}{c}\text { Grading } \\
\text { (Histological differentiation } \\
\text { of primary tumor) }\end{array}$} & \multicolumn{4}{|c|}{$\mathrm{T}$ classification } & \multicolumn{3}{|c|}{$\begin{array}{c}\text { Presence of local lymph } \\
\text { node metastasis }\end{array}$} & \multicolumn{2}{|c|}{$\begin{array}{c}\text { Presence of distant } \\
\text { metastasis }\end{array}$} \\
\hline & G1 & G2 & G3 & $\mathrm{T} 1$ & $\mathrm{~T} 2$ & $\mathrm{~T} 3$ & $\mathrm{~T} 4$ & No & & & No & Yes \\
\hline & & & & & & & & No & N1 & $\mathrm{N} 2$ & M0 & M1 \\
\hline Number of patients (n) & 16 & 16 & 16 & 10 & 13 & 14 & 11 & 15 & 28 & 5 & 43 & 5 \\
\hline
\end{tabular}

antibiotics: penicillin (100 IU/ml), streptomycin $(50 \mu \mathrm{g} / \mathrm{ml})$, neomycin $(100 \mu \mathrm{g} / \mathrm{ml})$, Germany).

Evaluation of NKT cell proliferation. $10^{6}$ NKT cells were incubated for 72 hours with $1.5 \mu \mathrm{M} / \mathrm{ml}$ COX-2 inhibitor (celecoxib, Calbiochem, Germany). NKT cells $\left(1 \times 10^{6}\right)$ were also co-incubated with $\left(1 \times 10^{4}\right)$ DCs-stimulated with cell lysates derived from LC tumors, and additionally combined with $1.5 \mu \mathrm{M} / \mathrm{ml}$ COX-2 inhibitor. The assessment of the in vitro proliferation of NKT cells was conducted using a thymidine incorporation assay (methyl-3 H/Thymidine, Lecomed LtD, Czech Republic) as described previously (14)

Statistical analysis. Statistical analysis was performed using Statistica 9.0 software (StatSoft, USA) using The Mann-Whitney $U$-test and the Wilcoxon matched-pairs signed-ranks test. All results are showed as mean \pm SEM. $p$-Values lower than 0.05 were considered significant.

\section{Results}

In order to assess the effect of the in vitro generated LCstimulated dendritic cells (LC-DCs) on the proliferation of NKT cells and the influence of the COX-2 inhibitor on this process, equal amounts $\left(1 \times 10^{6}\right)$ of NKT cells were treated according to the following combinations: 1) control NKT cells without treatment; 2) NKT cells with COX-2 inhibitor; 3) NKT cells co-stimulated with DCs; and 4) NKT cells co-stimulated with DCs and incubated with COX-2 inhibitor. The same combinations were performed on NKT cells derived from the patients control group. There were no statistically significant differences in NKT cells proliferation derived from the control group of patients regardless of the type of stimulation or treatment. However, control-group NKT cells had a higher proliferation rate than those isolated from LC patients, irrespectively of the treatment (Figure 1).

Analyzing the LC group, a statistically significant decrease of NKT cells proliferation was found when cocultured with generated LC-DCs $(p<0.0001)$ compared to control NKT cells (Figure 2, first and second bar, respectively). This phenomenon was ameliorated, when

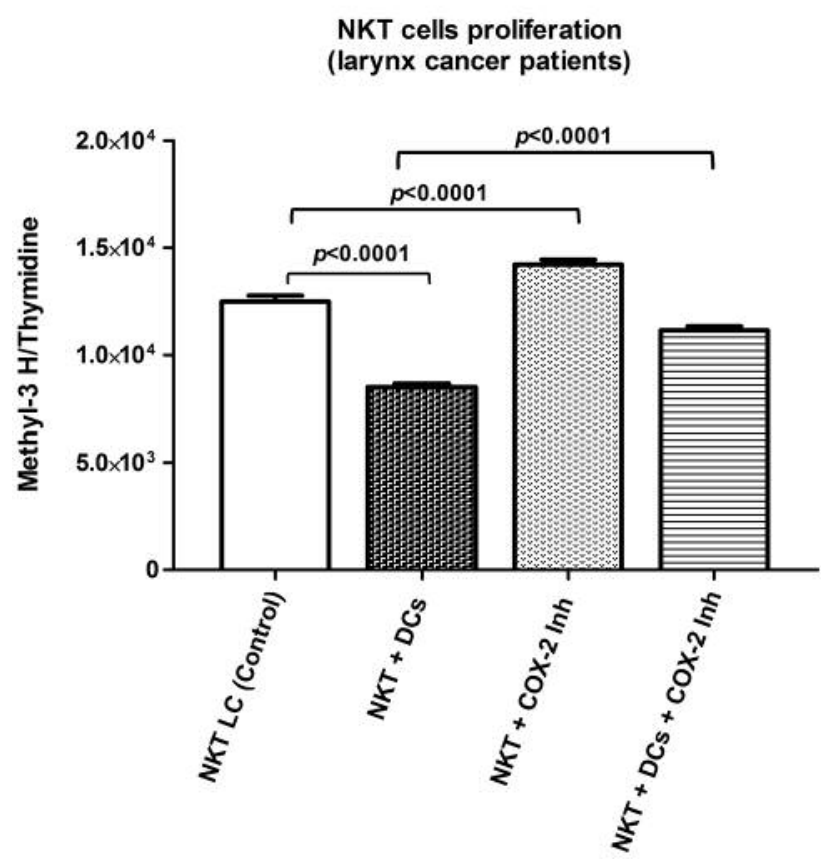

Figure 2. Analysis of NKT cells proliferation of larynx cancer $(L C)$ patients using ${ }^{3} \mathrm{H}$-thymidine incorporation assay. Values represent means \pm SEM.

COX-2 inhibitor celecoxib (COX-2-inh) was added to the LC-DCs stimulated NKT cells (Figure 2, second and fourth bar, respectively), demonstrating that the proliferation of LCDCs-stimulated NKT cells in the presence of COX-2 inhibitor was significantly higher as compared to NKT cells and DCs without COX-2 inhibition $(p<0.0001)$. Similarly, proliferation of NKT cells (LC patients group) cultured in the presence of COX-2-inh was significantly higher $(p<0.0001)$ than NKT cells (LC patients group) without the inhibitor in the medium (Figure 2, first and third bar, respectively). Detailed data are depicted in Table II. These observations clearly show that COX-2 inhibition resulted in a higher proliferation of NKT cells derived from LC patients, in contrast to control patients. 
A

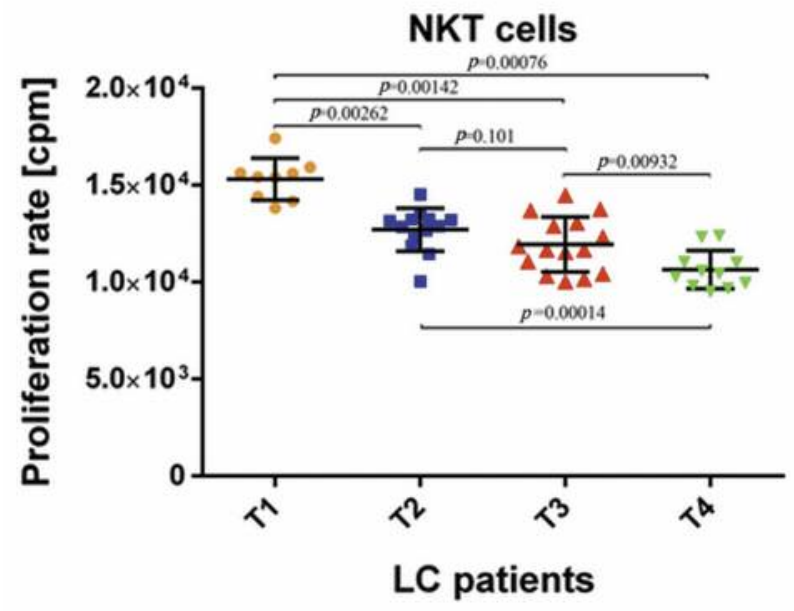

C

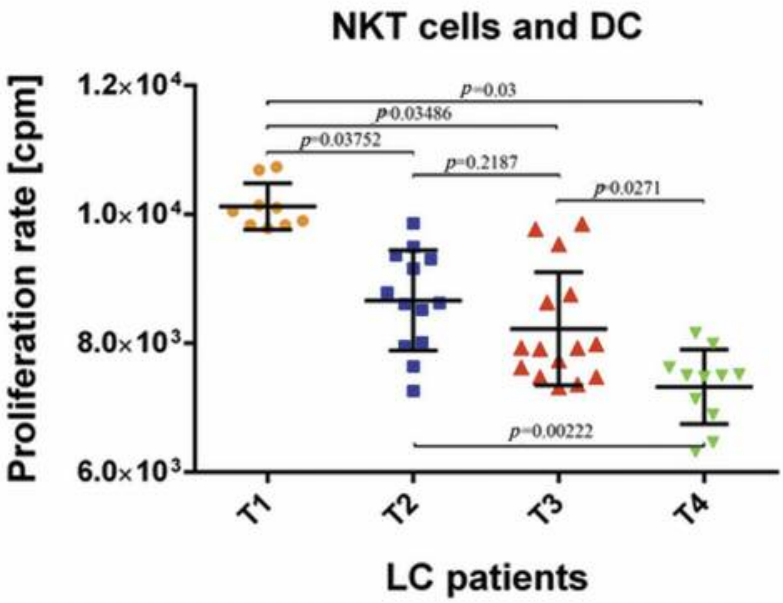

B

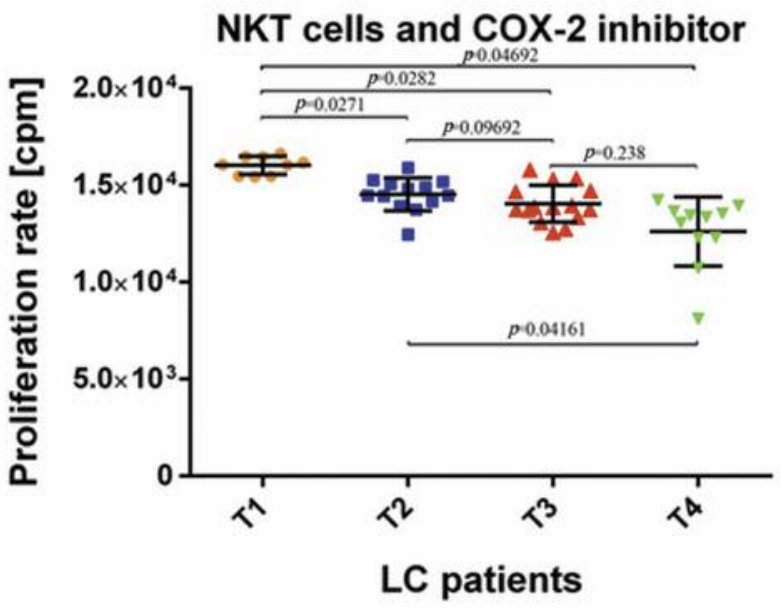

D

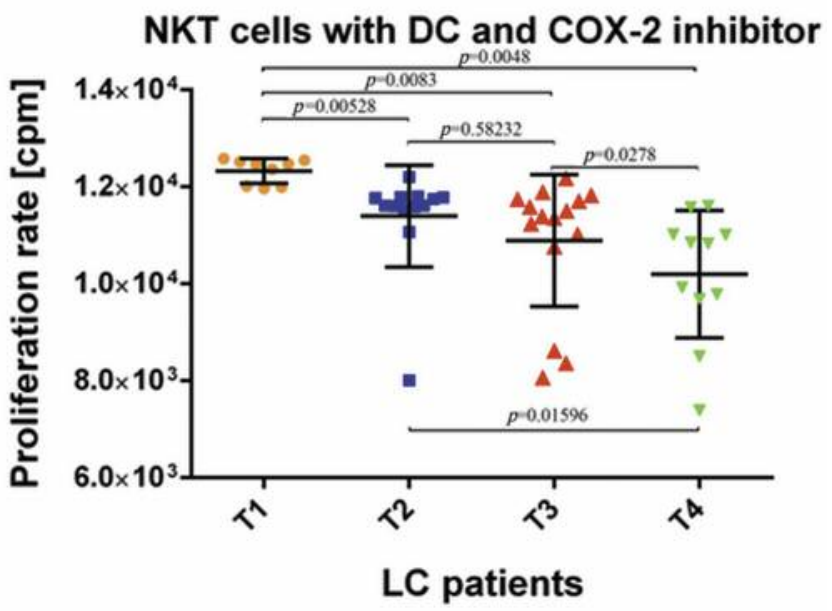

Figure 3. NKT cells proliferation in patients groups according to tumor volume and localisation (T1-T4).

Table II. Analysis of NKT cells proliferation of larynx cancer (LC) patients using ${ }^{3} \mathrm{H}$-thymidine incorporation assay.

\begin{tabular}{lcc}
\hline Proliferation rate of NKT cells in cultures $[\mathrm{cpm}]$ & Mean \pm SEM & Median (range) \\
\hline NKT LC (Control) & $12482.96 \pm 279.46$ & $12387.00(9528.91-17428.55)$ \\
NKT + DCs & $8492.93 \pm 166.79$ & $8086.50(6317.00-10736.49)$ \\
NKT + COX-2 Inh & $14214.71 \pm 225.46$ & $14191.20(8115.21-16631.70)$ \\
NKT + DCs + COX-2 lnh & $11136.40 \pm 189.65$ & $11598.00(7391.47-12583.34)$ \\
\hline
\end{tabular}

Results represent the mean \pm SEM. $p$ calculated using Wilcoxon matched pairs test.

Our study also revealed that the NKT cell proliferation intensity was closely related to the clinical settings of LC and was the highest in LC patients in not advanced stages - small laryngeal tumors (T1) or when metastases were not detectable (N0), showing decrease of NKT cells proliferation along with more advanced stages of the disease (Figures 3 and 4). There were no statistically significant differences of NKT cells proliferation in relation to the tumor localization (glottic, transglottic and supraglottic, data not shown). 
A

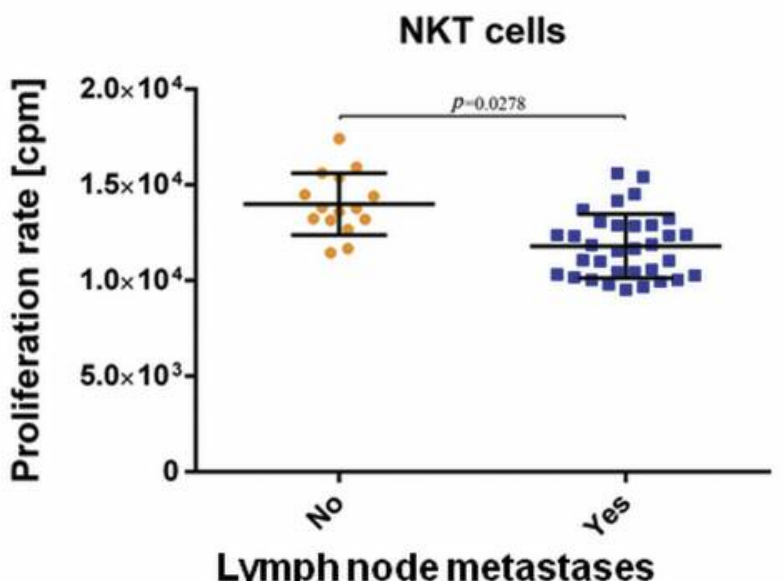

C

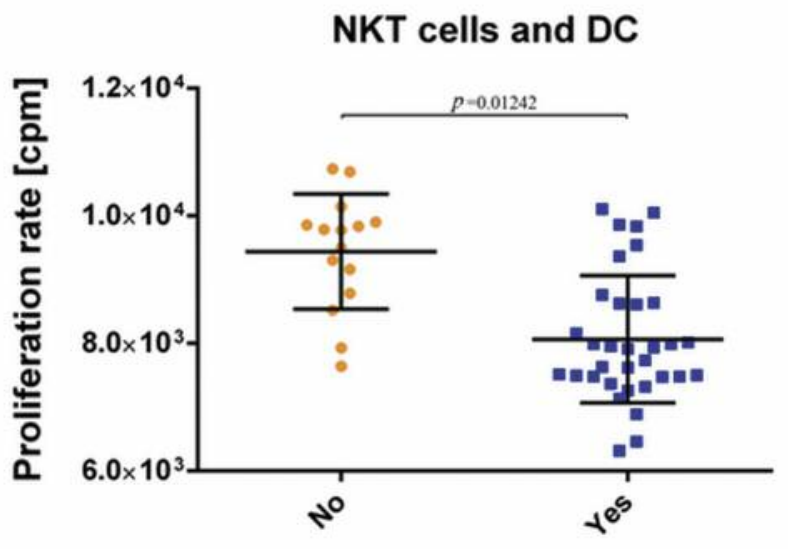

Lymph node metastases
B

NKT cells and COX-2 inhibitor

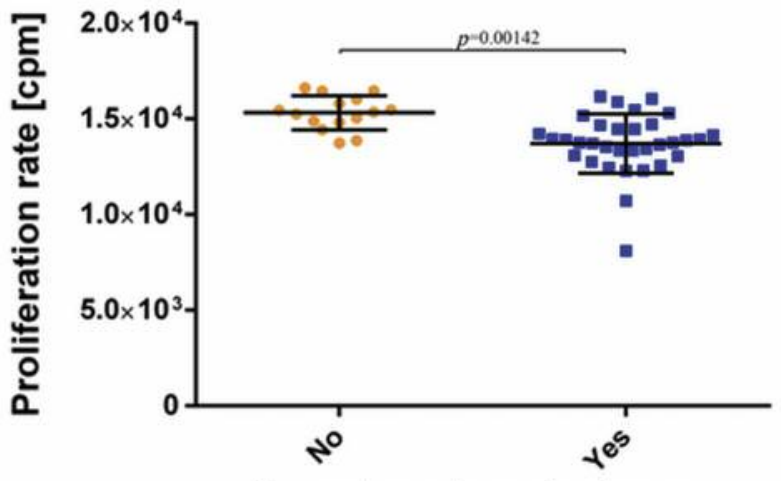

Lymph node metastases

D

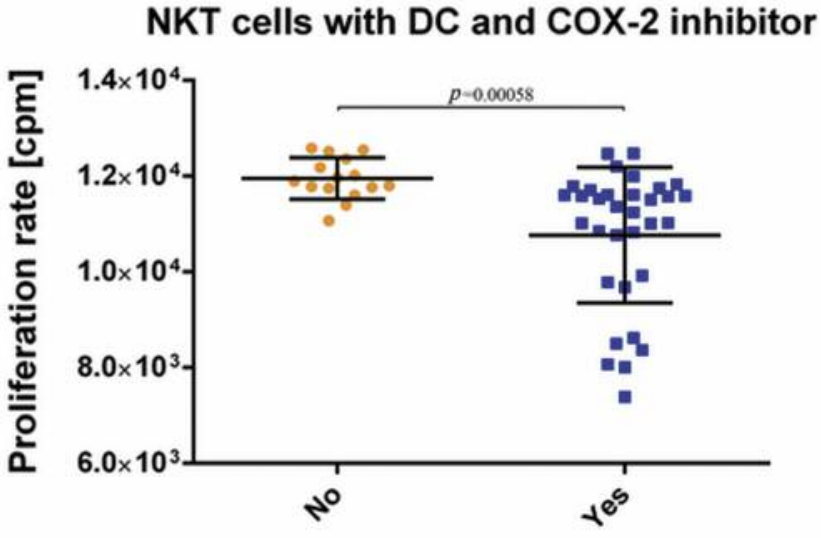

Lymph node metastases

Figure 4. NKT cells proliferation analyzed in patient groups with or without regional lymph node metastasis.

Moreover, LC tumors from patients classified as having a G1 degree of histological differentiation were characterized by the highest NKT cells proliferation rate as compared to G2 and G3 histopathological grading (Figure 5).

\section{Discussion}

Inadequate presentation of tumor antigens by antigen presenting cells (APCs), including DCs, is a known mechanism for tumors to escape the immune defense system (15). Tumor-derived COX-2 and its downstream effectors, adversely affect DCs maturation and function (16), thus impairing the innate immune system reaction to tumor growth. Moreover, in HNSCC patients the number of myeloid-derived DCs has been described as significantly lower than in controls, which could additionally contribute to the failure in the development of effective antitumor immune responses in these patients (17). DCs-based vaccination trials have been performed for some cancers, however, DCs stimulated solely with tumor cell lysates provided limited immune responses (18). In our study, we observed a decrease of NKT cells proliferation, when coincubated with LC-stimulated DCs. This could suggest that either LC-stimulated DCs are immature and thereby fail to efficiently activate NKT cells, or laryngeal tumor cells do not express positive costimulatory molecules, resulting in impairment of DCs function. Tumor cells often downregulate antigen presentation by antigen loss (19), or produce 
A

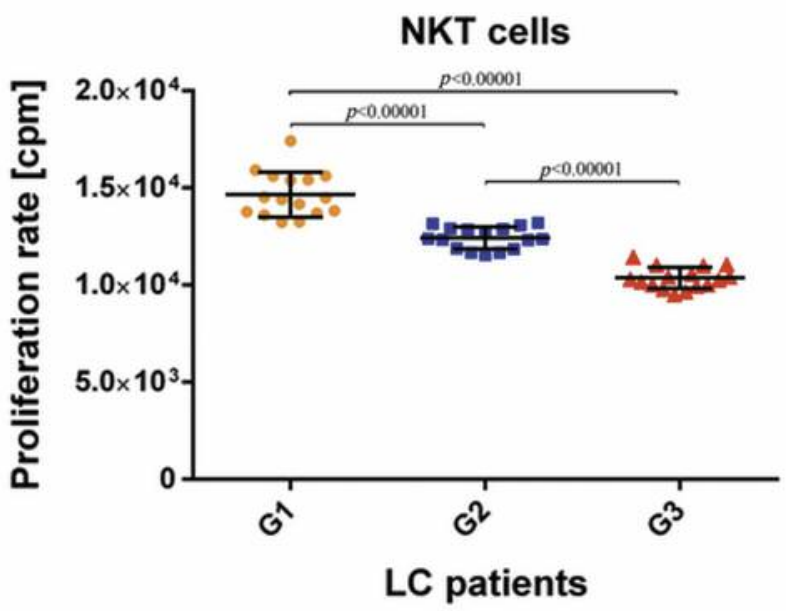

C

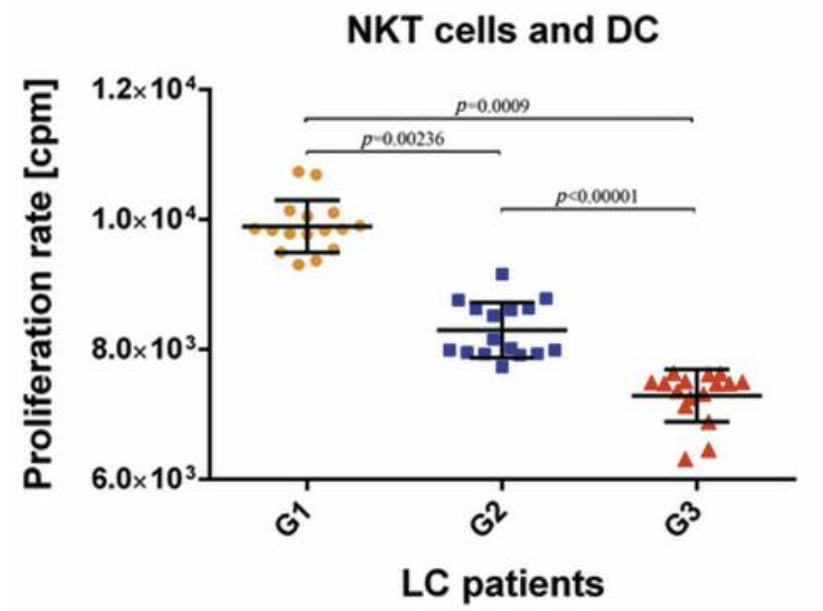

B

NKT cells and COX-2 inhibitor

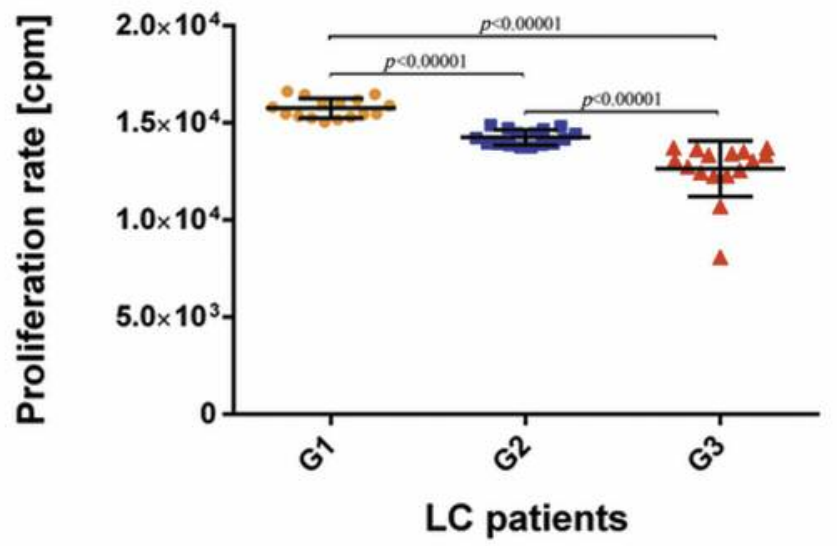

D

\section{NKT cells with DC and COX-2 inhibitor}

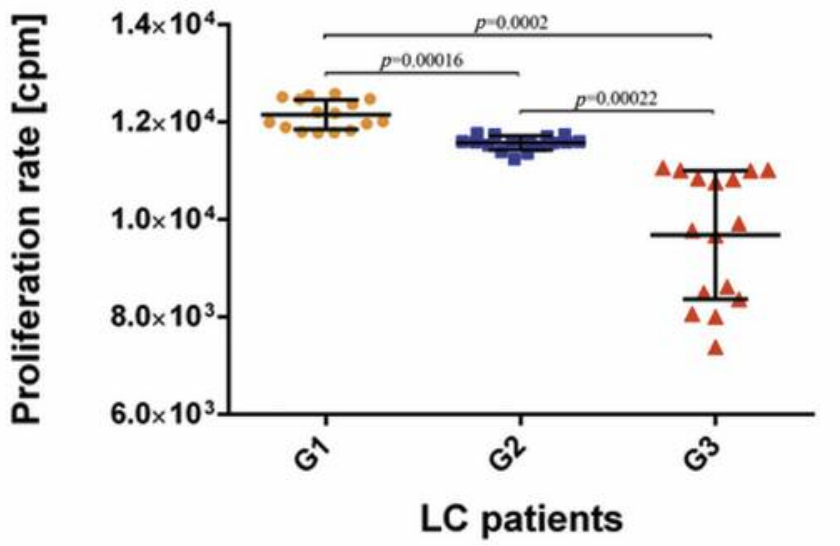

Figure 5. NKT cells proliferation according to histological grading (G1-G3).

high amounts of growth factors (VEGF, IL-6, IL-10,TGF-b, M-CSF) and COX-2, which can impair the differentiation, maturation and function of DCs (20). Interestingly, we observed that inhibition of COX-2 augmented proliferation of NKT cells, which theoretically could improve the efficiency of DCs-NKT-based immunotherapy. NKT cells are indirectly involved in inhibiting tumor angiogenesis and enhancing antigen-specific immune responses (20). On the other hand, NKT cells directly kill tumor cells by an NK-like effector mechanism, based on perforin and granzyme B cytotoxicity (20). In light of facts that diminished the number of circulating NKT cells has been proposed as an independent predictor of poor overall survival and diseasefree survival in patients with head and neck squamous cell carcinoma (20). The strategy to increase the amount of NKT cells by inhibiting COX-2 activity could have a positive value for cancer patients. Independent studies highlighted COX-2 inhibition as a promising therapeutic strategy for head and neck cancer. The administration of COX-2 inhibitor resulted in anticancer effects in HNSCC via cellular and molecular mechanisms (21). Moreover, COX-2 inhibitors might play a role in enhancing the effects of radiotherapy or chemotherapeutic drugs in $\operatorname{HNSCC}(22,23)$. On the basis of our results, it seems that DCs-NKT-based immunotherapy could be more effective in not advanced laryngeal cancers since a higher proliferation rate of NKT cells was achieved in non-metastatic and highly differentiated LC. Similar observations were made in patients with progressive multiple myeloma, prostate cancer and other solid tumors showing impairment of function and reduction in number of 
peripheral blood NKT cells in more advanced cancers (20). In addition, pharmacological inhibition of tumor COX-2 leads to restoration of DCs function, effective antitumor immune responses (24), and increased susceptibility of colon cancer cells to NK cells treated with celecoxib (25). Thereby, as observed in our study, COX-2 inhibition-mediated increase of NKT cells proliferation ameliorated LC-DCs negative influence, which could play a role in the efficiency of immunotherapy treatment regimens.

In conclusion, our in vitro study suggests the use the COX2 inhibitor in order to increase the effectiveness of vaccines containing DCs in patients with LC. However, additional studies are required to improve DCs-based vaccines therapy before they could be considered as practical alternatives to the existing treatment strategies of laryngeal cancers.

\section{Acknowledgements}

This work was supported by research grant no. NN403 104240 from the Polish State Funds for Scientific Research. The Authors would like to thank Prof. Adolfo Rivero-Muller for the critical review of the manuscript.

\section{References}

1 Klatka J, Grywalska E, Klatka M, Wasiak M, Andrzejczak A and Rolinski J: Expression of selected regulatory molecules on the $\mathrm{CD} 3^{+}$monocyte-derived dendritic cells generated from patients with laryngeal cancer and their clinical significance. Eur Arch Otorhinolaryngol 270: 2683-2693, 2013.

2 Sakakura K, Chikamatsu K, Takahashi K, Whiteside TL and Furuya N: Maturation of circulating dendritic cells and imbalance of T-cell subsets in patients with squamous cell carcinoma of the head and neck. Cancer Immunol Immunother 55: 151-159, 2006

3 Tzeng A, Kauke MJ, Zhu EF, Moynihan KD, Opel CF, Yang NJ, Mehta N, Kelly RL, Szeto GL, Overwijk WW, Irvine DJ and Wittrup KD: Temporally Programmed CD8alpha+ DC Activation Enhances Combination Cancer Immunotherapy. Cell reports 17: 2503-2511, 2016.

4 Pletinckx K, Dohler A, Pavlovic V and Lutz MB: Role of dendritic cell maturity/costimulation for generation, homeostasis, and suppressive activity of regulatory T cells. Front Immunol 2: 39, 2011.

5 Yu X, Yang Y, Yuan H, Wu M, Li S, Gong W, Yu J, Xia W, Zhang Y, Ding G, Huang S, Jia Z and Zhang A: Inhibition of COX-2/PGE2 cascade ameliorates cisplatin-induced mesangial cell apoptosis. American J Translational Res 9: 1222-1229, 2017.

6 Sung MW, Lee DY, Park SW, Oh SM, Choi JJ, Shin ES, Kwon SK, Ahn SH and Kim YH: Celecoxib enhances the inhibitory effect of 5-FU on human squamous cell carcinoma proliferation by ROS production. Laryngoscope 127: E117-E123, 2017.

7 Hu H, Han T, Zhuo M, Wu LL, Yuan C, Wu L, Lei W, Jiao F and Wang LW: Elevated COX-2 expression promotes angiogenesis through EGFR/p38-MAPK/Sp1-dependent signalling in pancreatic cancer. Sci Rep 7: 470, 2017.

8 Yukawa T, Shimizu K, Maeda A, Yasuda K, Saisho S, Okita R and Nakata M: Cyclooxygenase-2 genetic variants influence intratumoral infiltration of Foxp3-positive regulatory $\mathrm{T}$ cells in non-small cell lung cancer. Oncol Rep 33: 74-80, 2015.

9 Gebremeskel S, Clattenburg DR, Slauenwhite D, Lobert L and Johnston B: Natural killer $\mathrm{T}$ cell activation overcomes immunosuppression to enhance clearance of postsurgical breast cancer metastasis in mice. Oncoimmunology 4: e995562, 2015.

10 Exley MA, Friedlander P, Alatrakchi N, Vriend L, Yue S, Sasada T, Zeng W, Mizukami Y, Clark J, Nemer D, LeClair K, Canning C, Daley H, Dranoff G, Giobbie-Hurder A, Hodi FS, Ritz J and Balk SP: Adoptive transfer of invariant NKT cells as immunotherapy for advanced melanoma: A phase I clinical trial. Clin Cancer Res, 2017. doi: 10.1158/1078-0432.CCR-16-0600. [Epub ahead of print]

11 Vo MC, Lee HJ, Kim JS, Hoang MD, Choi NR, Rhee JH, Lakshmanan VK, Shin SJ and Lee JJ: Dendritic cell vaccination with a toll-like receptor agonist derived from mycobacteria enhances anti-tumor immunity. Oncotarget 6: 33781-33790, 2015.

12 Arora P, Baena A, Yu KO, Saini NK, Kharkwal SS, Goldberg MF, Kunnath-Velayudhan S, Carreno LJ, Venkataswamy MM, Kim J, Lazar-Molnar E, Lauvau G, Chang YT, Liu Z, Bittman R, Al-Shamkhani A, Cox LR, Jervis PJ, Veerapen N, Besra GS and Porcelli SA: A single subset of dendritic cells controls the cytokine bias of natural killer $\mathrm{T}$ cell responses to diverse glycolipid antigens. Immunity 40: 105-116, 2014.

13 Macho-Fernandez E, Cruz LJ, Ghinnagow R, Fontaine J, Bialecki E, Frisch B, Trottein F and Faveeuw C: Targeted delivery of alpha-galactosylceramide to CD8alpha ${ }^{+}$dendritic cells optimizes type I NKT cell-based antitumor responses. J Immunol 193: 961-969, 2014.

14 Klatka M, Kaszubowska L, Grywalska E, Wasiak M, Szewczyk L, Foerster J, Cyman M and Rolinski J: Treatment of Graves' disease with methimazole in children alters the proliferation of Treg cells and $\mathrm{CD}^{+} \mathrm{T}$ lymphocytes. Folia Histochem Cytobiol 52: 69-77, 2014.

15 Perrot I, Blanchard D, Freymond N, Isaac S, Guibert B, Pacheco $\mathrm{Y}$ and Lebecque S: Dendritic cells infiltrating human non-small cell lung cancer are blocked at immature stage. J Immunol 178: 2763-2769, 2007.

16 Pandey VK, Amin PJ and Shankar BS: COX-2 inhibitor prevents tumor induced down regulation of classical DC lineage specific transcription factor Zbtb46 resulting in immunocompetent DC and decreased tumor burden. Immunol Lett 184: 23-33, 2017.

17 Nguyen N, Bellile E, Thomas D, McHugh J, Rozek L, Virani S, Peterson L, Carey TE, Walline H, Moyer J, Spector M, Perim D, Prince M, McLean S, Bradford CR, Taylor JM, Wolf GT, Head and Neck SPI: Tumor infiltrating lymphocytes and survival in patients with head and neck squamous cell carcinoma. Head Neck 38: 1074-1084, 2016.

18 Wei FQ, Sun W, Wong TS, Gao W, Wen YH, Wei JW, Wei Y and Wen WP: Eliciting cytotoxic T lymphocytes against human laryngeal cancer-derived antigens: evaluation of dendritic cells pulsed with a heat-treated tumor lysate and other antigen-loading strategies for dendritic-cell-based vaccination. J Exp Clin Cancer Res 35: 18, 2016.

19 Subrahmanyam PB, Sun W, East JE, Li J and Webb TJ: Natural killer $\mathrm{T}$ cell based Immunotherapy. Journal of vaccines \& vaccination 3: 144, 2012.

20 Cali B, Molon B and Viola A: Tuning cancer fate: the unremitting role of host immunity. Open Biol 7(4): pii: 170006, 2017. 
21 Kim YY, Lee EJ, Kim YK, Kim SM, Park JY, Myoung H and Kim MJ: Anti-cancer effects of celecoxib in head and neck carcinoma. Mol Cells 29: 185-194, 2010.

22 Abrahao AC, Giudice FS, Sperandio FF and Pinto Junior Ddos S: Effects of celecoxib treatment over the AKT pathway in head and neck squamous cell carcinoma. J Oral Pathol Med 42: 793798, 2013

23 Shin DM, Zhang H, Saba NF, Chen AY, Nannapaneni S, Amin AR, Muller S, Lewis M, Sica G, Kono S, Brandes JC, Grist WJ, Moreno-Williams R, Beitler JJ, Thomas SM, Chen Z, Shin HJ, Grandis JR, Khuri FR and Chen ZG: Chemoprevention of head and neck cancer by simultaneous blocking of epidermal growth factor receptor and cyclooxygenase- 2 signaling pathways: preclinical and clinical studies. Clin Cancer Res 19: 1244-1256, 2013.
24 Sharma S, Stolina M, Yang SC, Baratelli F, Lin JF, Atianzar K, Luo J, Zhu L, Lin Y, Huang M, Dohadwala M, Batra RK and Dubinett SM: Tumor cyclooxygenase 2-dependent suppression of dendritic cell function. Clin Cancer Res 9: 961-968, 2003.

25 Kim SJ, Ha GH, Bae JH, Kim GR, Son CH, Park YS, Yang K, Oh SO, Kim SH and Kang CD: COX-2- and endoplasmic reticulum stress-independent induction of ULBP-1 and enhancement of sensitivity to NK cell-mediated cytotoxicity by celecoxib in colon cancer cells. Exp Cell Res 330: 451-459, 2015.

Received June 2, 2017

Revised June 16, 2017

Accepted June 19, 2017 